Ur Språk \& stil NF 29, 2019

\title{
Att koka ihop ett beslut \\ En multimodal interaktionsanalys av gemensamt besluts- fattande i vardagen
}

\author{
AV KLARA BERTILS \& SIMON MAGNUSSON
}

\begin{abstract}
Bertils, Klara, klara.bertils@lingfil.uu.se, Ph.D. student, Department of Linguistics and Philology, Uppsala University, Sweden. Magnusson, Simon, simon.magnusson@sh.se, Ph.D. student, School of Culture and Education, Södertörn University, Sweden: "Sharing decisions in the kitchen: A multimodal interaction analysis of joint decision-making in an everyday setting." Språk och stil NF 29, 2019, pp. 73-98.

This study explores the social organization and the necessary involvement in accomplishing sharedness in joint decision-making, by adopting a members' perspective on food preparation. Prior research on joint decision-making has mostly focused on verbal analysis of institutional interactions, e.g. medical encounters. In contrast, the current study carries out a multimodal interaction analysis of joint decision-making in everyday informal cooking among friends. The analysis demonstrates a crucial function of embodied actions, such as bodily stance, eye gaze and manipulation of objects, in organizing and coordinating decision-making sequences. Since the decisions in this particular setting often are based on a multisensory access to the objects of decision, establishing and displaying epistemic access comprise a constitutive part of joint decision-making. In line with this, we show that not allowing for an epistemically equal point of departure, the participants may be sanctioned when not accessing the empirical object of decision, e.g., not tasting the sauce. In addition to shedding light on the temporal organization of actions and the epistemic access central to organizing joint decision-making, the study offers an understanding of how participants as social actors constitute themselves as friends and family by means of making decisions shared in the midst of a mundane activity that constitutes daily life.
\end{abstract}

Keywords: decision-making, multimodality, participation, access, multisensoriality, conversation analysis, everyday interaction.

Varje dag fattar vi individuella och gemensamma, stora och små beslut. Vissa beslut fattas på rationella grunder, andra utifrån empiriska förnimmelser av världen. Ett sammanhang som innefattar många beslut av det senare slaget är

Vi vill tacka Clara Iversen, Marie Flinkfeldt och två anonyma granskare för insiktsfulla kommentarer på tidigare versioner av denna artikel. Vi vill också tacka alla deltagare som generöst och modigt välkomnat oss in i sina kök. 
matlagning. När man lagar mat tillsammans med familj och vänner behöver man enas om huruvida såsen är tillräckligt saltad och när klyftpotatisen börjar få fin färg och ska sättas på eftervärme. Dessutom behöver man finna lösningar på problem som uppstår under matlagningens gång, så att matlagningen inte stannar upp för att majonnäsen visar sig ha tagit slut. För att gemensamt gå från förslag till genomförande krävs kommunikativa praktiker, vilka vi i denna studie kommer att utforska med hjälp av multimodal interaktionsanalys.

Gemensamt beslutsfattande innebär dock inte bara att lösa problem och att effektivt uppnå resultat. Det handlar också om att i den sociala samvaron faktiskt göra besluten till gemensamt åstadkomna och således delade. Studier av beslutsfattande visar att människor tycks sträva mot att göra beslut just delade snarare än enskilt fattade (Stevanovic 2012, Koenig 2011, Landmark m.fl. 2015). För att fatta ett gemensamt beslut behöver deltagarna vara överens om både var i beslutsfattandesekvensen de befinner sig - om beslutet är fastställt eller fortfarande under förhandling - och beslutets innehåll - vad det är man faktiskt enas om (Stevanovic m.fl. 2017). Man behöver också visa varandra att man har den kunskap som krävs för att på goda grunder fatta beslut. Allt detta görs $\mathrm{i}$ interaktionen genom ständigt säkerställande och uppvisande av delad förståelse deltagarna emellan.

I föreliggande undersökning studerar vi gemensamt beslutsfattande i ett vardagligt sammanhang. Studien anlägger ett etnometodologiskt och samtalsanalytiskt perspektiv (se t.ex. Goodwin 2000, Schegloff 1996) och utgår från videoinspelningar av personer som lagar mat tillsammans i sina hem. Då tidigare samtalsanalytisk forskning har haft stark slagsida åt beslutsfattande i institutionella kontexter, särskilt läkare-patientsamtal (för en översikt, se t.ex. Landmark 2016), utgörs vårt bidrag särskilt av att vi studerar beslutsfattande i vardagen. Vi bidrar också med ett multimodalt perspektiv (Goodwin 2000, Mondada 2018a) på beslutsfattande, då vi studerar hur det koordineras i interaktion ansikte-mot-ansikte genom samordnandet av kroppar, objekt och verbala element. Studien ger dessutom en fördjupad förståelse för hur beslutsfattande görs till någonting gemensamt genom att närmare fokusera på hur deltagare förhåller sig till att skaffa och uppvisa tillgång till det som de ska fatta beslut om. I samband med detta diskuterar vi hur deltagarnas subjektiva upplevelser och erfarenheter av t.ex. smak behandlas som en förutsättning för att göra ett beslut till något som fattas gemensamt. 


\section{Gemensam matlagning som interaktion och kontext för beslutsfattande}

Matens och ätandets sociala betydelse märks i de många studier som har synliggjort social praktik genom att analysera situationer där mat har en central roll (se t.ex. Wiggins m.fl. 2001). Medan samtalsanalysen har en lång tradition av att studera samtal vid middagsbordet, har dock få studier fokuserat på den interaktion som sker medan maten tillreds. Några undantag utgör Stukenbrocks (2012) studie om interaktion mellan en tv-kock, en gäst och åskådare, Goldbergs (1975) studie med deltagare som följer ett recept och Conein (1997) om receptens roll för hur man dukar ett bord. Mondada (2014a) och Raevaara (2017) fokuserar båda på instruktioner i matlagningskurser. Mondada (2014a) undersöker hur råvaror manipuleras och transformeras till relevanta ingredienser i relation till kursledarens instruktioner, medan Raevaara (2017) studerar hur en ledare för en matlagningskurs för barn utformar sina anvisningar. Ursi (2016) undersöker hur oenigheter uppstår och utvecklas sekventiellt vid gemensam matlagning. Vad tidigare forskning visar är att köket är en viktig plats för social interaktion och att matlagning är en aktivitet som kräver noggrann koordinering mellan deltagare och med omgivande objekt. Allt detta gör matlagning till en kontext väl lämpad för att undersöka gemensamt handlande och beslutsfattande i ett vardagligt sammanhang.

Matlagning utmärker sig också genom att smakupplevelser och smakande är viktiga komponenter i aktiviteten. Att smak och smakande inte enbart ska ses som neurologiska och kognitiva processer, utan att de även kan betraktas utifrån sociala perspektiv, har lyfts i tidigare interaktionellt orienterad forskning (Wiggins \& Potter 2003; Mondada 2018b, 2018c, 2019, u.å.). Eftersom vi är intresserade av hur deltagare orienterar sig mot att skaffa sig tillgång till och kunskap om det som beslutet gäller, samt hur subjektiva upplevelser av olika objekt blir relevanta i beslutsfattandeprocessen, framstår matlagning som en intressant multisensorisk aktivitet.

\section{Beslutsfattande i interaktion}

Gemensamt beslutsfattande har inom samtalsanalytisk forskning främst studerats i medicinsk interaktion. ${ }^{1}$ Studier i denna kontext visar hur patienter

${ }^{1}$ I dessa sammanhang används i regel termen delat beslutsfattande (shared decision-making). Denna är etablerad i en vårdvetenskaplig kontext (se t.ex. Socialstyrelsen 2012), och framstår som en institutionell term snarare än grundad i detaljerad analys av interaktion. I samtalsanalytiska studier i andra kontexter än den medicinska används ibland termen gemensamt beslutsfattande (joint decision-making, se t.ex. Stevanovic 2012). I denna studie använder vi oss av den termen. 
kan delta i och bidra till beslut genom att verbalt och kroppsligt uppvisa instämmande eller motstånd mot läkarens behandlingsrekommendationer (se t.ex. Costello \& Roberts 2001; Stivers 2005a, 2005b, 2006; Koenig 2011; Hultberg \& Rudebeck 2017), samt hur läkare och patienter kan konstruera beslutsfattandesekvenser som mer eller mindre delade (Collins m.fl. 2005, Koenig 2011, Toerien m.fl. 2013, Landmark m.fl. 2015, Barnes 2017, Stivers m.fl. 2017). Utanför en medicinsk kontext har bl.a. Stevanovic och Peräkylä (2012) och Stevanovic (2012) undersökt gemensamt beslutsfattande i dyadiska arbetsplatsmöten. De menar att det i gemensamt beslutsfattande alltid ingår förhandling om deontiska rättigheter, d.v.s. deltagares auktoritet att fatta beslut. En deltagare som håller med om innehållet i ett beslut kan ändå göra motstånd mot dess deontiska aspekter genom att positionera sig som självständig. Beslutsfattande är dock inte begränsat till institutionellt präglade samtal, utan förekommer frekvent även i »vardagliga» aktiviteter. En beslutsfattandeprocess i institutionella samtal kan vara mer eller mindre formaliserad och behandlas som begränsad av sina deltagarramar (jfr Robinson 2003). Inte minst kan deltagares orientering mot asymmetriska institutionella roller (t.ex. läkare och patient) påverka hur beslutsfattandeprocessen går till. Vardaglig interaktion erbjuder delvis andra förutsättningar för lansering av förslag, för koordinering av hur beslutfattandet sker gemensamt och för att avgöra när en beslutsfattandesekvens är mogen för avslut.

Tidigare samtalsforskning har beskrivit beslutsfattandesekvensen som inledd av ett förslag som så småningom godtas (Houtkoop 1987, Stevanovic m.fl. 2017). Genom att lägga fram ett förslag öppnar talaren för att andra deltagare har rätten och skyldigheten att delta i beslutsfattandet (Charles m.fl. 1997, Stevanovic 2012, Stevanovic \& Peräkylä 2012). Talaren bjuder alltså in andra att delta i processen och indikerar att beslutet ska fattas gemensamt. Närhetsparet förslag-godtagande (Schegloff 2007) kan betraktas som kärnan i beslutsfattandesekvensen (Stevanovic m.fl. 2017) och kan ensamt utgöra sekvensen, såsom när en deltagare lägger fram ett förslag som omedelbart godtas av samtalspartnern (Stasser \& Stewart 1992). Det är dock inte ovanligt att sekvensen expanderas med ytterligare underordnade närhetspar, varför beslutsfattandesekvensen kan karaktäriseras som vad Schegloff (2007 s. 252) kallar »a sequence of sequences».

Ett gemensamt beslut kräver enligt Stevanovic (2012) att den som mottar ett förslag (proposal) 1) skaffar sig tillgång till förslagets innehåll (access), 2) instämmer i samtalspartnerns förslag (agreement) och 3) förbinder sig till den fö- 
reslagna framtida handlingen (commitment). Utifrån detta föreslås följande modell för uppkomsten av ett gemensamt beslut.

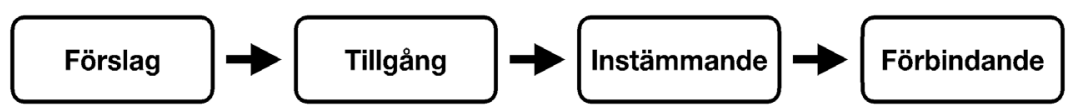

(Stevanovic 2012 s. 785, vår övers.)

Längs vägen kan förslaget avslås, vilket Stevanovic (2012) benämner som ett icke-beslut, eller konstrueras som ett unilateralt (icke-gemensamt) beslut. Detta sker genom att en deltagare undviker något av stegen: att skaffa tillgång, att instämma i förslaget eller att förbinda sig till handlingen. En deltagare kan också underminera och avstå sin rätt att delta i beslutsfattandet genom att hävda okunskap, d.v.s. avsaknad av epistemisk tillgång, eller avsaknad av deontisk auktoritet, d.v.s. rätten att fatta beslut (Landmark m.fl. 2015, Lindström \& Weatherall 2015).

Tidigare forskning har visat att beslutsfattandesekvenser kan inledas av bland annat frågor, påståenden och erbjudanden (se t.ex. Stivers m.fl. 2017). Dessutom framstår icke-verbala handlingar som högst centrala resurser för att initiera en förändring i gemensamt handlande (Stevanovic \& Monzoni 2016). Stevanovic m.fl. (2017) använder därför termen aktivitetshanterande drag (activity-management moves), definierat som en handling (verbal eller kroppslig) som påverkar ett gemensamt handlingsförlopp genom att föreslå inledning, förändring eller avslutande av en gemensam handling. Förslag, främst igenkännbara genom sin lingvistiska form (Stevanovic 2012 s. 782), framstår utifrån detta som en alltför begränsad term för ett förstadrag i en beslutsfattandesekvens. I föreliggande artikel tillämpar vi därför Stevanovic (2012) modell utifrån en breddad förståelse för vad som kan inleda en beslutsfattandesekvens. Alla former av förstadrag som kan initiera gemensam handling, i vårt fall beslutsfattande, kallar vi handlingsinitiativ. Att en deltagare verbalt eller kroppsligt föreslår hur någonting kan utföras kallar vi, oberoende av sekventiell position och modalitet, för förslag.

Vi förstår det gemensamma i gemensamt beslutsfattande som deltagande $\mathrm{i}$ beslutsprocessen. Goodwin och Goodwin (2004) presenterar ett ramverk för deltagande där samtliga närvarande betraktas som aktiva deltagare i interaktionen. ${ }^{2}$ Oavhängigt deltagarnas verbala bidrag till interaktionen så är samtliga att

${ }^{2}$ Detta ramverk utgör delvis en kritik av Goffmans (1981) verbalfokuserade modell för deltagande som fokuserar den talande deltagaren. 
betrakta som aktörer som genom sin kroppsliga hållning, sitt blickspel och sin kropps förhållande till objekt i omgivningen visar upp sitt deltagande i pågående skeenden. I linje med detta utgår vi från Goodwin och Goodwins definition av deltagande som "actions demonstrating forms of involvement performed by parties within evolving structures of talk» (2004 s. 222).

En central resurs för att åstadkomma och visa upp engagemang i en gemensam handling är kroppens placering i rummet och gentemot andra kroppar och objekt. Positionering av den egna kroppen har beskrivits som synliga praktiker för att åstadkomma olika hållningar (eng. stances) inför en förelagd uppgift i den sociala interaktionen (Goodwin 2007). Att till exempel placera sin kropp så att man ser hur den andre hackar grönsaker åstadkommer en rad olika hållningar. Goodwin (2007) identifierar fem typer av hållningar med betydelse för deltagande. Man placerar sig själv gentemot objekt och andra människor i omgivningen i en instrumentell hållning så att man kan se, höra, förnimma så mycket som krävs för den relevanta aktiviteten. Positioneringen bidrar till en epistemisk hållning ${ }^{3}$ som demonstrerar att man har möjlighet att uppfatta och uppleva de betydelsefulla beståndsdelarna i den aktuella situationen. Därigenom visar deltagaren att man har inhämtat relevant information och därmed deltar på goda grunder i den gemensamma handlingen. Deltagarens kroppsliga position signalerar också huruvida man intar en samarbetande hållning (cooperative stance) inför aktiviteten och är del i dess genomförande. Utöver att uppvisa delaktighet, samarbetsvillighet och adekvat kunskapsinhämtning har kropparnas placering också moraliska och affektiva implikationer. En deltagare kan visa huruvida man litar på den andra personen och att den har de rätta förutsättningarna för att utföra sysslan genom att inta en moralisk hållning. Känsloyttringar kan markera affektiv hållning och sanktionera sådana handlingar som inte är i linje med det förväntade deltagandet. Vi återkommer i analyskapitlet till hur deltagare orienterar sig mot dessa kroppsliga hållningar som relevanta för adekvat deltagande i beslutsprocessen.

\section{Material och metod}

Föreliggande studie baseras på ca 150 beslutsfattandesekvenser ur ett videomaterial om 6,5 timmar, i vilka vänner och familjer lagar middag tillsammans.

\footnotetext{
${ }^{3}$ Goodwins användning av begreppet epistemic stance skiljer sig från användningen hos Heritage
} (2012), som främst utgår från den verbala turens grammatiska konstruktion. 
Deltagarna är i åldrarna 20-85 år och har varierande bakgrund, yrken och könsidentiteter. Datainsamlingen har skett i linje med Vetenskapsrådets forskningsetiska principer för humanistisk-samhällsvetenskaplig forskning (Vetenskapsrådet 2002). Deltagarna har muntligen och skriftligen informerats om studien och om sina rättigheter att dra tillbaka sin medverkan, samt gett sitt skriftliga samtycke till deltagande och till att författarna publicerar omaskerade bilder i vetenskapliga sammanhang. Materialet har transkriberats enligt Jeffersons (2004) principer för verbal transkription samt Mondadas (2014b) konventioner för multimodal transkription.

Inspelningarna analyseras genom etnometodologisk samtalsanalytisk metod (se t.ex. Schegloff 1996, Goodwin 2000). Det innebär att vi utifrån videoinspelningar av interaktion i detalj analyserar hur samtalsdeltagare gemensamt skapar och genomför sociala handlingar. Centralt är antagandet att handlingar skapas och tolkas sekventiellt, vilket innebär att betydelsen och utformningen av varje (verbal eller kroppslig) handling beror på vad som föregår den, samtidigt som varje handling förändrar kontexten och formar förutsättningarna för kommande handling. Därför kan handlingar inte analyseras isolerat utan måste förstås - av såväl samtalsdeltagare som forskare - utifrån i sin omedelbara kontext (Heritage 1984). I linje med Goodwin (2000) och Mondada (2018a) utgår vi från ett multimodalt perspektiv på språkande och social handling, där både verbala och kroppsliga handlingar samt interaktion med objekt ${ }^{4}$ i den omgivande miljön utgör semiotiska resurser för meningsskapande.

\section{Analys}

I det följande redovisar vi vår analys av beslutsfattandesekvenser i gemensam matlagning. I de tre första exemplen (1), (2) och (3) undersöks hur beslutsfattande initieras, koordineras och görs till en gemensam angelägenhet genom multimodala resurser. Det avslutande exemplet (4) fokuserar särskilt på det andra steget i Stevanovic (2012) modell för gemensamt beslutsfattande, nämligen tillgång till det som ska beslutas om. Vi resonerar här om hur deltagarna orienterar sig mot att skaffa och visa upp epistemisk tillgång som en förutsättning för deltagande och gemensamt beslutsfattande.

\footnotetext{
${ }^{4}$ Med objekt menas materiella ting som man kan se, höra eller röra (Nevile m.fl. 2014).
} 
(1) Hur stora bitar vill vi ha?

01

$$
\begin{array}{cc} 
& +(0,1) \#+(0,9) \\
\text { jon } & \text { tgreppar kniv+ } \\
\text { fig } & \text { \#fig. } 1
\end{array}
$$

02

jon

jon

noa

03 JON

jon

04 MIA

05 JON

mia

06

07

$$
\begin{array}{lll} 
& \text { fig } & \multicolumn{1}{c}{\text { \#fig. } 2} \\
08 & & (0,3) \\
09 & \text { MIA } & \text { @A: *precis } \\
& \text { jon } & \text { @lutar huvu } \\
& \text { mia } & \text { *lutar } \\
& \text { jon } & \\
& \text { jon } & \\
10 & \text { MIA } & =j a ̈ t t e b r a . \\
11 & & (0,5) *+\triangle \#
\end{array}
$$
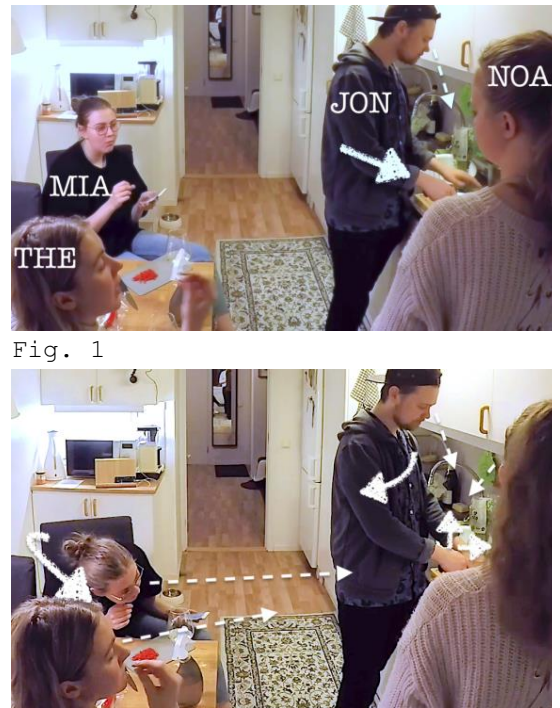

Fig. 2

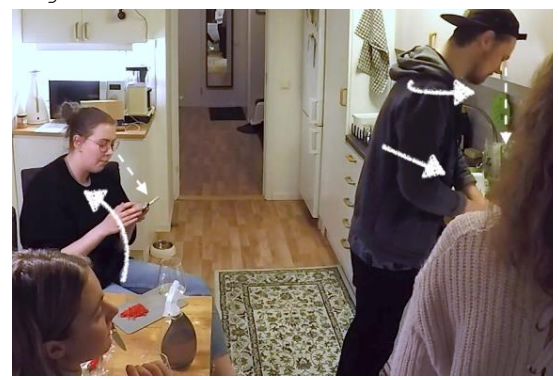

Fig. 3

Vårt första exempel (1) illustrerar hur deltagare multimodalt initierar och genomför ett gemensamt beslutsfattande i linje med Stevanovic (2012) modell. I exemplet lagar Mia, Noa, Jon och Therese mat tillsammans när Jon initierar ett gemensamt beslutsfattande angående hur bönorna ska skäras. ${ }^{5}$

Jon greppar kniven men börjar inte skära bönskidorna som ligger på skärbrädan utan stannar med kniven ovanför bönorna (fig. 1). Han ställer en fråga, formulerad med pronomenet vi, Hur stora bitar vill vi ha? ( $\operatorname{rad} 2-3)$. Jon framställer därmed bönskidornas storlek som ett beslut att fatta gemen-

\footnotetext{
${ }^{5}$ Transkriptionsnyckel baserad på Jefferson (2004) samt Mondada (2014b) finns bifogad.
} 
samt, grundat i deltagarnas vilja. Han vrider också överkroppen något mot Mia ( $\operatorname{rad} 2$; se position i fig. 2) i en s.k. body torque (jfr Schegloff 1998). Denna förändrade riktning av överkroppen signalerar en avvikelse från det pågående aktivitetsförloppet, som ska återtas när beslutsfattandesekvensen är avslutad. Hans fråga, tillsammans med hans förändrade kroppsposition, utgör ett handlingsinitiativ som inleder en beslutsfattandesekvens. Noa och Mia orienterar sig omedelbart mot skärbrädan: Noa genom att vända blicken däråt, och Mia genom att luta sig framåt mot Jon och skärbrädan (fig. 2). De skaffar sig därmed tillgång till det beslutet gäller: De kan se bönorna och skärbrädan. Genom denna position intar de en epistemisk hållning (Goodwin 2007) som demonstrerar att de inhämtar relevant kunskap och därmed kan delta adekvat i beslutsfattandet. Genom sina kroppspositioner visar deltagarna synbart sitt deltagande i beslutsfattandet. Jon föreslår därpå storlek

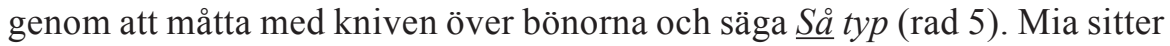
kvar i sin framåtlutade ställning med blicken mot skärbrädan och ser Jons förslag - hon möjliggör fortsatt tillgång till det som beslutet gäller och visar sig fortsatt involverad i beslutsfattandet. Därpå lutar hon sig tillbaka och instämmer verbalt i förslaget ( $r a d ~ 9-10)$. Jon omsätter omedelbart förslaget i handling genom att skära bönorna enligt förslaget (fig. 3) och visar sig därmed beredvillig till det gemensamt fattade beslutet. Exemplet visar hur ett beslutsfattande lanseras som en gemensam uppgift varpå deltagarna skaffar sig tillgång till beslutets objekt (genom blickriktning, kroppspositioner och verbala uttryck) och därmed visar sitt engagemang. Först efter att den visuella tillgången är säkrad accepteras förslaget och genomförs.

Genom dessa steg i beslutsprocessen behöver deltagarna i ett gemensamt beslutsfattande vara överens om både var de befinner sig i beslutsprocessen och vad de beslutar om (jfr Stevanovic m.fl. 2017). I följande exempel (2) vill vi just visa hur deltagarna, med sina kroppar i interaktion i det materiella rummet, koordinerar beslutsfattandets steg när de förkastar och återupptar förslag på handling. Då förslagen gäller materiella objekt i deltagarnas omedelbara omgivning, blir det särskilt relevant att undersöka hur hantering av objekt blir en del av att orientera sig i sekvensen. I exemplet är vännerna Erik och Max i färd med att lösa ett problem som uppstått under matlagningen, nämligen att en ingrediens saknas. Max har gjort slut på majonnäsen, och de behöver nu hitta en ersättning när Erik ska laga coleslaw. Erik har föreslagit att ersätta majonnäsen med dijonsenap eller att göra egen majonnäs. Max har ställt sig avvaktande till förslagen, dock utan att explicit avvisa dem. När utdraget börjar står de båda och tittar in i kylskåpet efter 
(2) Den sista majonnäsen
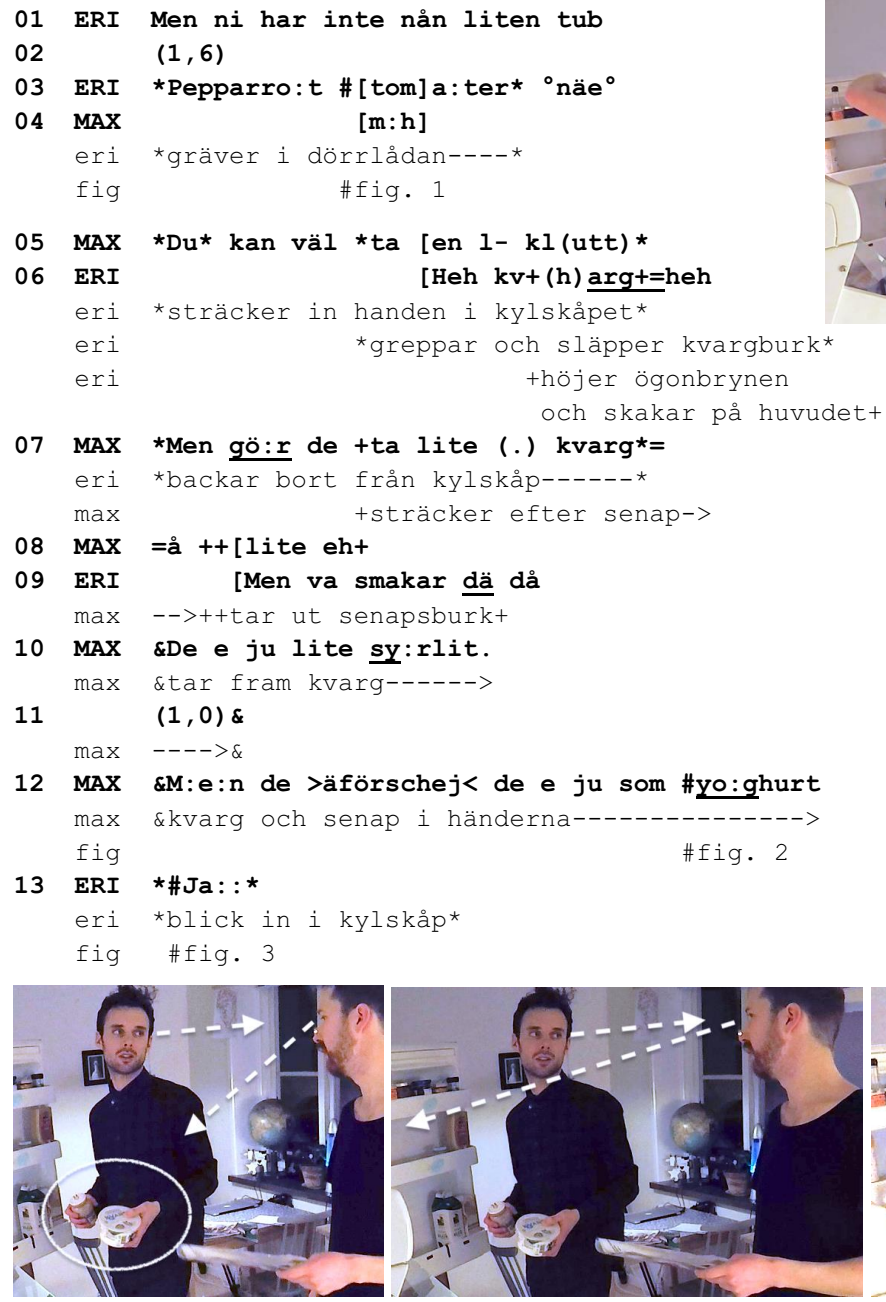

Fig. 2
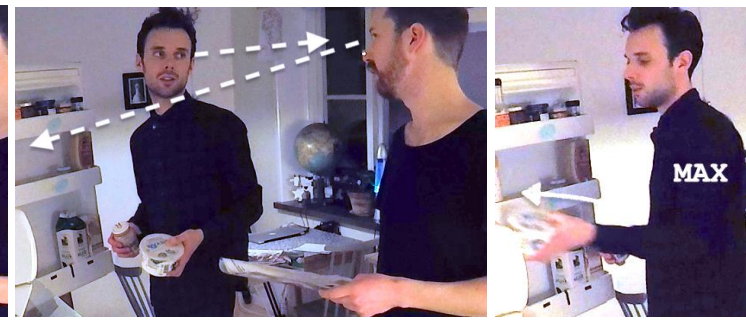

$14 \quad(0,4)$

15 ERI \&\&Nä: \#de kanske inte gör\& från eller till

fig \#fig. 4

max ->\&\&ställer in kvarg i kylskåpet\&

16 MAX >Men \#d-< \#men du kan\#ske* kan ta dig en li:ten li:ten*= fig \#fig.5 \#fig.6 \#fig.7

eri

17 MAX =*\#skvätt* e: :h

eri *tar senap*

fig \#fig. 8 


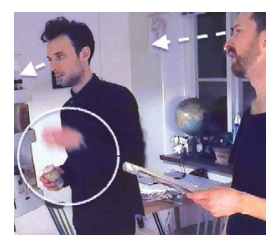

Fig. 5

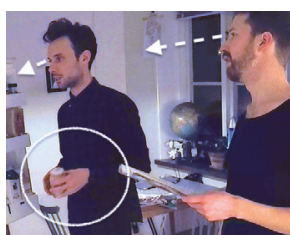

Fig. 6 .

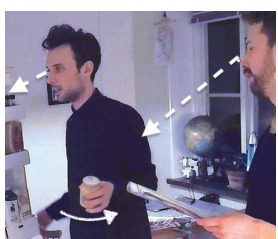

Fig. 7

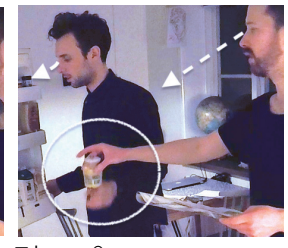

Fig. 8

18 ERI Å så säger vi att det är maxs fel att de ( )

19 MAX Mm,

någonting annat som kan ersätta majonnäsen. Vi fokuserar i denna analys på hur Max och Erik förkastar och återupptar förslag, och hur de koordinerar beslutsfattandesekvensen genom blickspel, kroppsposition och hantering av objekt.

Deltagarna inventerar kylskåpet $\mathrm{i}$ jakt på någonting som kan lösa det uppkomna problemet ( $\operatorname{rad} 1-4)$. Max påbörjar ett handlingsinitiativ i form av ett förslag ( rad 5), möjligen gällande den tidigare idén att använda dijonsenap. Samtidigt uppmärksammar och sträcker sig Erik efter en burk i kylskåpet, lyfter upp den och annonserar med skrattande röst och skämtsamt ansiktsuttryck dess innehåll kvarg (rad 6). Därpå släpper han burken igen ( $\operatorname{rad} 6)$ och rör sig bort från kylskåpet ( $\operatorname{rad} 7)$, och förkastar därmed vad som kunde ha varit ett potentiellt förslag att använda kvarg. Max står dock kvar i samma position som tidigare, riktad mot kylskåpet. Samtidigt som Erik backar från kylskåpet uppmanar Max honom att faktiskt använda kvargen: Men gö:r de ta lite kvarg (rad 7). Eriks omnämnande av sitt kylskåpsfynd kvarg ( $\operatorname{rad} 6)$ aktualiseras därmed som ett relevant förslag. Max explicitgör det som ett förslag genom imperativen $g o ̈: r$ och $t a$. Erik frågar hur kvarg smakar ( $\operatorname{rad} 9)$. Genom sin fråga söker han adekvat epistemisk tillgång i form av kunskap om kvargens smakegenskaper. Därmed visar han sig involverad i beslutsfattandet, och behandlar kvargen som ett relevant förslag. Medan Max besvarar frågan ( $r a d ~ 10)$ tar han fram kvargen ur kylskåpet igen, tillsammans med den dijonsenap som tidigare föreslagits som potentiell kandidat. Genom att åter föra fram objektet från en sovande position (se Bergmann 1990) behandlar Max det som ett fortsatt aktuellt förslag. Därpå (rad 12) påpekar Max att kvarg kanske är att jämställa med ingrediensen yoghurt, som redan är nedblandad i coleslawen. Det inledande $M e:: n$ samt äförschej ('i och för sig') formulerar detta som en invändning, vilket projicerar ett avvisande av förslaget. Erik instämmer i invändningen (rad 13), vilket Max behandlar som ett förkastande av förslaget då han ställer tillbaka kvargen i kylskåpet (rad 15). Förslaget att använda kvarg är nu slutgiltigt 
avvisat. Däremot behåller Max dijonsenapen i handen och modifierar därpå sitt tidigare förslag om att använda den till att Erik kanske kan ta dig en li:ten li:ten skvätt ( $\operatorname{rad} 16-17)$. Dijonsenapen har hållits kvar som fortsatt relevant under tiden de har diskuterat ett annat lösningsalternativ. Erik går med på förslaget att använda dijonsenap på villkoret att de inför matgästerna lägger ansvaret på Max ( $\operatorname{rad} 18)$.

Genom sin bibehållna kroppsposition riktad mot kylskåpet (fig. 1-8), till skillnad från Erik som med kropp och blick rör sig bort (rad 7), uppehåller sig Max vid Eriks förslag om kvarg som ännu aktuellt. Medan Erik behandlar beslutsfattandesekvensen som avslutad och förslaget som förkastat, håller Max sekvensen vid liv genom att behålla sin kroppsposition och genom att återuppväcka det objekt - kvargburken - som Erik ställt tillbaka när han avvisade sitt eget skämtsamt inramade förslag. Så länge förslaget är uppe på bordet som aktuell kandidat, hålls objektet också aktuellt i rummet (jfr Keisanen \& Rauniomaa 2012). När deltagarna sedan enas om att denna del av beslutsfattandesekvensen är avslutad och förslaget är förkastat, sätts kvargen tillbaka i kylskåpet och behandlas inte längre som ett relevant förslagsobjekt (jfr Rauniomaa \& Heinemann 2014, Day \& Wagner 2014).

Vi har i detta exempel sökt visa hur kroppsposition, blickar och hantering av objekt är centrala resurser för att koordinera beslutsfattande. Förslag framförs och hanteras genom att göra förslagsobjekten framskjutna i den kontextuella konfigurationen (Goodwin 2000). Genom att flytta förslagsobjektet fram och tillbaka, i det här fallet en burk kvarg, och genom att orientera sig mot den plats där objektet finns, i det här fallet kylskåpet, upprätthåller deltagarna en intersubjektiv uppfattning om huruvida beslutsfattandesekvensen är pågående eller avslutad samt huruvida objektet ännu är aktuellt som förslag (jfr Stevanovic m.fl. 2017). Genom att lyfta fram kvargen, titta på den och resonera om dess egenskaper, skaffar sig deltagarna också den kunskap som krävs för att fatta ett gemensamt beslut. De visar att de deltar i beslutsfattandet, och behandlar samtidigt kvargen som ett relevant och aktuellt förslag.

Betydelsen av kroppslig position, blickar och hantering av objekt för att koordinera beslutsfattande är särskilt framträdande i följande exempel (3). Här visar sig deltagarna angelägna om att grundligt bevittna och åskådliggöra varje steg i vad som visar sig bli en komplex beslutsfattandesekvens. I utdraget gör Max och Erik klyftpotatis i ugnen. Erik står och diskar med ryggen vänd mot spisen. Utdraget inleds med att Max böjer sig ner och tittar in i ugnen. ${ }^{6}$

\footnotetext{
${ }^{6}$ Den inledande turen är ett skämtsamt dialektalt uttalat 'Ge dig nu' som hör till föregående topik.
} 
(3) Sänka värmen på potatisen

01

$\star(2,0) *$

max *går mot spisen, böjer sig och tittar in i ugnen*

02 MAX Ji: \#da no:,

fig \#fig. 1

03 MAX Aa @men\# potatisen@ börjar se lite e:h=

eri @böjer sig, tittar in i ugne

fig \#fig. 2
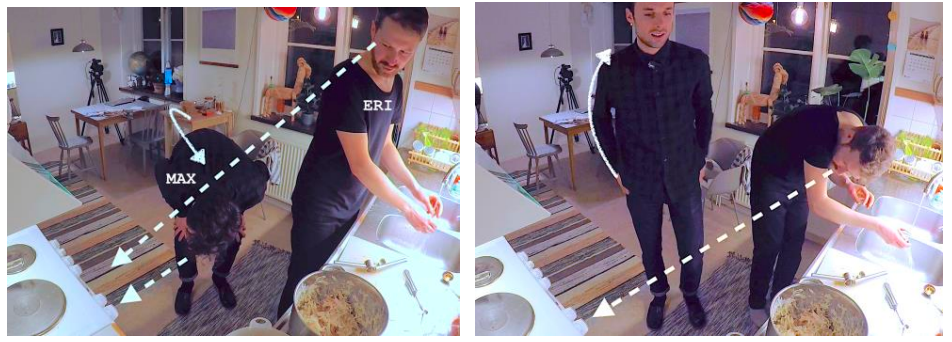

Fig. 1

Fig. 2

$04 \operatorname{MAX}=($.$) [härlig ut.$

05 ERI [Man kanske kan sä- man skulle kunna sä- för

06 den har ju \#redan fått $y$ : ta *man skulle ju så här

$\max$

*närmar sig spis-->

fig \#fig. 3

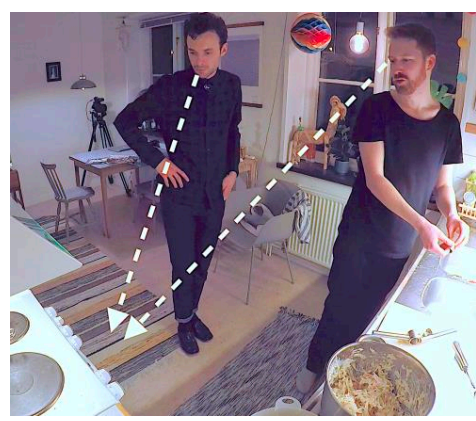

Fig. 3

07

08 MAX

$\max$

fig

09 MAX

fig

10 kunna* sänka *värmen \#om man inte [vil] att de ska* [Ja: :

*vrider vred till 150 \#fig. 4

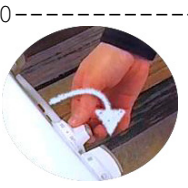

fig \#fig. 5 \#fig. 6 
86 Klara Bertils \& Simon Magnusson
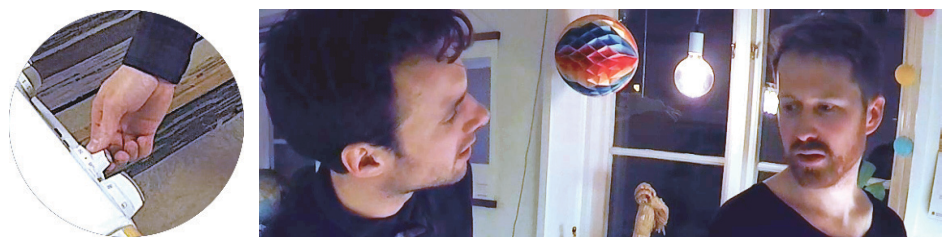

Fig. 5
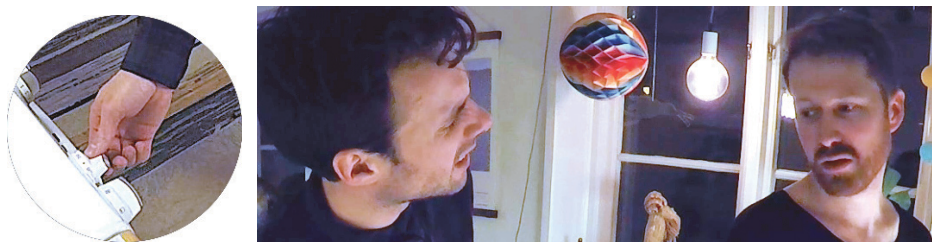

Fig. 6

11 ERI Aa eller tvåhu- *ja* eller hundra*sj*uttifem kanske? $\max \quad{ }^{*}$ vrider* ${ }^{*}$ vrider*

$12 *() * \$.

max *släpper vred*

fig \#fig $\cdot 7$
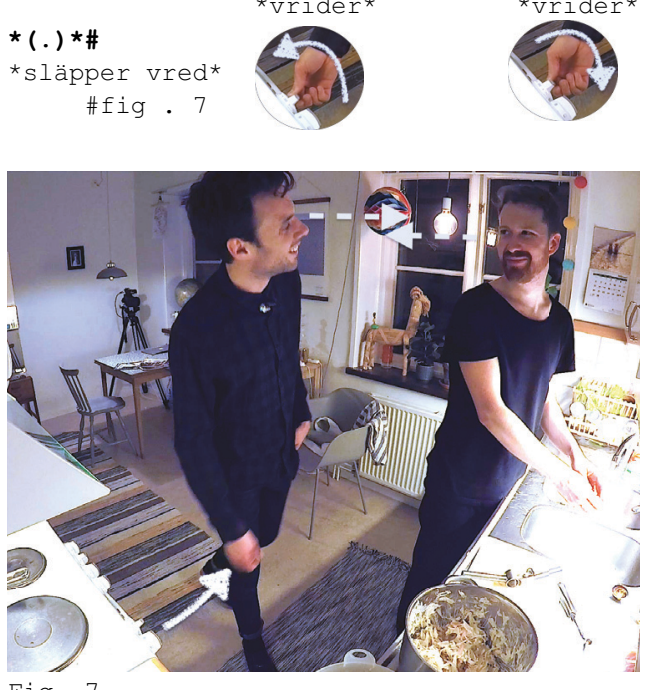

Fig. 7

13 MAX he:h

14 ERI För det var ju tvåhundratjugi.

15 MAX Ja.

$16 \quad(2,0)$

17 ERI Då blir de så där perfekt

18 MAX Ja-ö? ((förställd röst)) 
Max närmar sig spisen, böjer sig fram och tittar in i ugnen (fig. 1) varefter han rapporterar att potatisen börjar se lite härlig ut. Under Max' värdering böjer sig Erik och tittar även han in i ugnen och skaffar sig därmed tillgång till en egen uppfattning om potatisen (fig. 2). Han behandlar Max' värdering som ett handlingsinitiativ och visar att han deltar. Max och Erik ser till att båda inta samma epistemiska hållning, det vill säga ha och uppvisa möjlighet att förnimma potatisen och skapa sig en adekvat uppfattning om dess tillstånd (Goodwin 2000). Denna kunskap ligger till grund för ett informerat gemensamt beslut. Erik påbörjar, avbryter och omformulerar ett förslag, formulerade som möjliga handlingar med nedgraderad modalitet: man kanske kan sä- man skulle kunna sä( rad 5). I sin tredje omstart inleder han med motiveringen att potatisen redan har fått yta, och uttalar därpå ett förslag på handling. Redan efter motiveringen, innan förslaget har uttalats i sin helhet, närmar sig Max spisen och greppar ugnsvredet (fig. 4), och visar att han förbinder sig att agera i linje med förslaget. Han påbörjar omedelbart en sänkning till 150 grader, varpå han verbalt instämmer i förslaget $(\operatorname{rad} 8)$.

Beslutet att sänka värmen behöver nu finkalibreras genom ett följande beslut om vilken den nya temperaturen ska vara. Max framför verbalt ett förslag om 150 grader (rad 9). Hans förslag är markerat som just ett initialt sådant genom både lingvistiska och kroppsliga resurser: Den uppåtgående intonationen med svagare volym mot slutet ger förslaget en frågande karaktär, samtidigt som han håller handen fortsatt på vredet och vänder huvudet mot Erik och möter hans blick. Max för också samman ögonbrynen och skapar en s.k. orosrynka i pannan, samtidigt som han spänner upp överläppen och visar övre tandraden (fig. 5, fig. 6), ett ansiktsuttryck som i tidigare forskning har beskrivits som tecken på epistemisk utmaning (jfr Kaukomaa m.fl. 2014). I detta exempel föreslår vi att Max' ansiktsuttryck fungerar som ett sätt att öppna upp för problematisering och modifikation av hans föregående handling att sänka värmen till 150 grader. Därmed visar Max att beslutsfattandesekvensen ännu inte är fullbordad trots att han faktiskt redan kan tyckas ha genomfört sitt förslag. Max genomförda justering av ugnsvredet kan utifrån detta förstås som att han har börjat genomföra förslaget att sänka värmen, snarare än att på eget bevåg besluta vilken den nya temperaturen ska vara. Han markerar att beslutsfattandesekvensen fortfarande pågår och att hans förslag ännu är uppe för förhandling.

Erik svarar med att vicka huvudet åt sidan samtidigt som han höjer ögonbrynen något (fig. 6). Därpå accepterar han initialt förslaget genom $A a$, följt av motförslaget eller tvåhu- varpå han reparerar med upprepad ja eller-inledd konstruktion ja eller hundrasjuttifem kanske? ( rad 11). Max vrider vredet till det föreslagna gradantalet i direkt anslutning till Eriks båda förslag, och Erik behåller blicken vid vre- 
det under hela samtalsturen. Max släpper vredet på 175 grader och skrattar (fig. 7), och Erik fortsätter med att motivera sitt förslag. Max instämmer och efter en två sekunders paus driver Erik sekvensen mot avslut genom att göra en värdering (Schegloff 2007 s. 123) med humoristiskt förställd röst Då blir de så där perfekt ${ }_{\dot{c}}$ ( $\operatorname{rad} 17)$. Den besvaras instämmande av Max ( $\operatorname{rad} 18)$ som även prosodiskt matchar Eriks röstläge och därmed uppvisar affiliering (Couper-Kuhlen 2012). Den gemensamma förställningen av rösten skulle kunna tolkas som att de uppmärksammar och ironiserar över noggrannheten i temperaturkompromissen.

Exemplet visar på flera aspekter av att göra beslut till gemensamt fattade. Både Max och Erik arrangerar sina kroppar så att de kan undersöka potatisens färg och skapa sig individuell empirisk grund för beslutsfattandet. Kropparnas placeringar utgör en hållning som visar att de är »appropriately cooperating in the joint accomplishment of the activity in progress» (Goodwin $2007 \mathrm{~s}$. 62) och gör sig till jämlikar i beslutsfattandet. Den triadiska uppställningen kropp-kropp-objekt skapar en gemensam fokuspunkt beskriven i tidigare forskning som central för mänsklig interaktion, språkande och intersubjektivitet (Tomasello 1999, Goodwin \& Duranti 1992). De intar båda en epistemisk hållning genom att skapa tillgång till det objekt som de ska besluta om. Genom att skaffa sig samma kunskap om objektet gör de sig epistemiskt likvärdiga i beslutet. Det påföljande utförandet av handlingen efter att de är överens om att värmen på potatisen ska sänkas görs även det gemensamt. Max' hand på vredet blir nytt fokus för den triadiska uppmärksamheten (se fig. 4) och efter en inledande förändring i gradantalet enligt Eriks förslag att sänka värmen vänder sig Max mot Erik för att förankra och modifiera det initiala förslaget att sänka till 150 grader. Genom ansiktsuttryck, prosodi och en bibehållen kroppsposition indikerar Max att sekvensen ännu inte är avslutad och håller öppet för fortsatt deltagande från Erik. Därigenom behandlas Erik som deltagande i beslutsprocessen även när det är Max som har handen på vredet och är den som instrumentellt genomför själva sänkningen. Intersubjektivitet upprätthålls både vad gäller beslutets innehåll - ugnstemperaturen - och vad gäller den sekventiella orienteringen i beslutsprocessen - att fastställa när beslutssekvensen avslutas (jfr Stevanovic m.fl. 2017).

I alla tre exempel som hittills har diskuterats skaffar alla deltagare synbart epistemisk tillgång till beslutsobjektet. I följande exempel (4) närstuderar vi just denna del i beslutsfattandet. Här presenteras ett avvikande exempel som synliggör vad som kan ske när en deltagare avstår från att skaffa sig adekvat kunskap om ett beslutsobjekt. Exemplet syftar till att stärka vår analys att deltagande och gemensamhet är tätt förknippade med att tillägna sig och uppvisa epistemisk tillgång, då den som inte skaffar sig sådan kan tillrättavisas och behandlas som inte tillräckligt deltagande. I följande exempel har Bea, Ida och ytterligare tre vänner en sås puttrande på spisen som nu ska smakas av. 
(4) Smaka av såsen

\begin{tabular}{|c|c|c|}
\hline $\begin{array}{l}01 \\
02\end{array}$ & IDA & $\begin{array}{l}\text { Har vi smakat ordentlit nu rå } \\
(0,4)\end{array}$ \\
\hline $\begin{array}{l}03 \\
04\end{array}$ & BEA & $\begin{array}{l}\mathrm{Nä}: j, \\
(0,4)\end{array}$ \\
\hline 05 & $\begin{array}{l}\text { IDA } \\
\text { bea } \\
\text { fig }\end{array}$ & $\begin{array}{l}\text { @̈̈: :h\# de (e ju)@ } \\
\text { @sträcker sig efter sked@ } \\
\quad \text { \#fig.1 }\end{array}$ \\
\hline 06 & $\begin{array}{l}\text { bea } \\
\text { fig }\end{array}$ & $\begin{array}{l}\text { @\# }(0,8) \\
\text { @sköljer av skeden--> } \\
\text { \#fig. } 2\end{array}$ \\
\hline 07 & $\begin{array}{l}\text { IDA } \\
\text { ida }\end{array}$ & $\begin{aligned} \text { Då tar } & \& j a \& \\
& \& \text { sked ner i gryta\& }\end{aligned}$ \\
\hline 08 & $\begin{array}{l}\text { BEA } \\
\text { bea }\end{array}$ & Ja: gör de du.@ \\
\hline 09 & bea & $\begin{array}{l}\text { @\# }(0,4) \text { @ } \\
\text { @lägger ifrån sig skeden } \\
\text { och vrider sig mot gryta@ }\end{array}$ \\
\hline
\end{tabular}

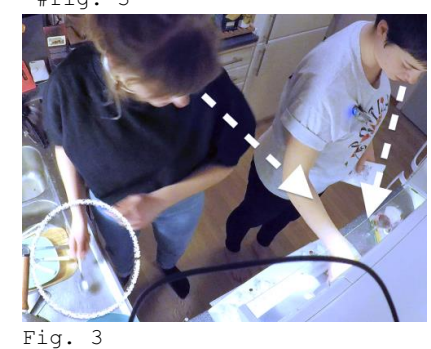
10 IDA Men $\uparrow$ gör $\uparrow$ de \#då fig \#fig. 4
11 BEA
12 ida
13 bea
ida bea fig
14
bea
ida
fig

\section{M: äh}
\&@ $(0,4) @$
\&blåser på sked->
eplockar upp skede
$\& \& @ \#(4,0) @$
$->\& \&$ smakar-->
etar smakprov ur grytae \#fig. 5
(a) $(4,0) \#(1,0) @ \&$
esmakar------e

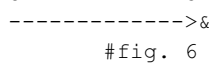

15 BEA
Ja tyck $(0,2)$ Lite mer salt.

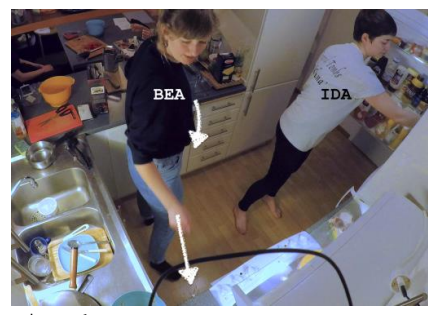

Fig. 1

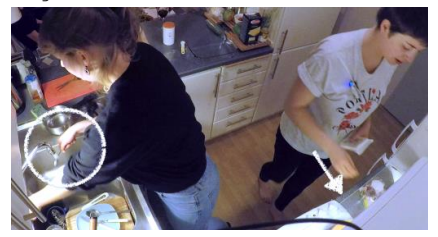

Fig. 2

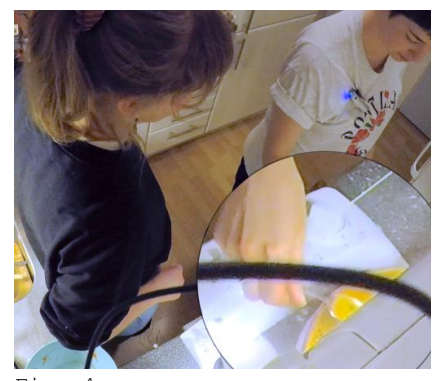

Fig. 4

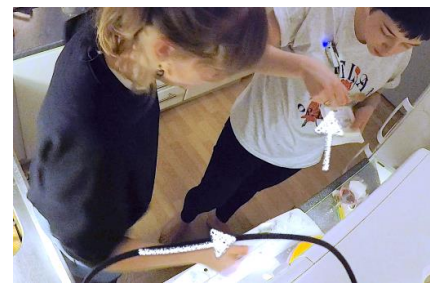

Fig. 5

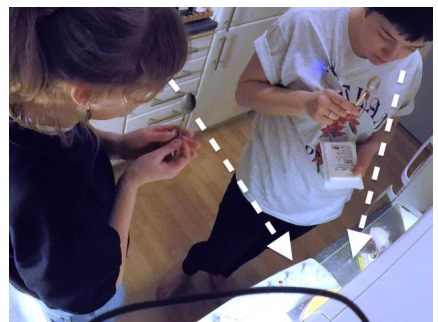

Fig. 6 
Ida frågar Har vi smakat ordentlit nu rå ( $\mathrm{rad} 1)$ och formulerar, genom pronomenet vi, smakandet som ett gemensamt ansvar. Bea svarar nekande på frågan ( $\mathrm{rad} 3)$ och behandlar den som ett handlingsinitiativ: Hon tar fram en tesked (fig. 1) som hon sköljer av i diskhon och förbereder sig således för att utföra den handling som saknas, dvs avsmakningen. Bea tar verbalt på sig uppdraget att smaka ( $\operatorname{rad} 7)$, samtidigt som hon tar fram en sked och därmed också kroppsligen visar att hon förbinder sig att utföra handlingen (fig. 2). Ida godtar Beas självrekrytering då hon explicit utnämner henne till den ansvariga att utföra smakandet Ja gör de $d u(\operatorname{rad} 8)$, samtidigt som hon själv lägger ifrån sig skeden och vänder sig mot Bea (fig. 3). Hon orienterar sig mot turen som ett förslag på arbetsfördelning och agerar som att hennes egen smakinsats nu skulle vara överflödig. Med Goodwins (2007) terminologi intar Ida en kooperativ hållning men inte instrumentell och epistemisk hållning. Genom att lägga ifrån sig skeden gör hon sig otillgänglig för att inhämta den kunskap som krävs för att bedöma såsen (instrumentell och epistemisk hållning), men genom sin kroppsliga orientering mot Bea (kooperativ hållning) deltar hon ändå i smakaktiviteten som icke-smakande åskådare. Bea uppmärksammar att Ida har förändrat sitt deltagande som nu består i att hon står lutad mot diskhon och iakttar Bea (fig. 4). Bea uppmanar henne med Men $\uparrow g \ddot{o r} \uparrow$ det då ( $\mathrm{rad} 10)$, inledd av men som positionerar turen som en invändning mot Idas föregående handling att lägga ifrån sig skeden. Turen fungerar som ett tillrättavisande och indikerar att Idas deltagande som vittne till avsmakningen snarare än som medsmakare inte är tillräckligt. Bea intar en affektiv hållning och reagerar med invändning och uppmaning som om Ida inte deltar korrekt när hon står bredvid och bara bevittnar avsmakningen istället för att själv smaka (jfr Goodwin 2007 s. 71). Att turen kan analyseras som en tillrättavisning och inte endast en uppmaning stöds av att Ida bemöter den med ett mäh innan hon följer uppmaningen. Partikeln mäh är oss veterligen inte beskrivet interaktionellt men framstår här som ett andra led efter en uppmaning mot vilket talaren gör motstånd. Den är således både misaligning och disafilliative (Heritage 1984 s. 269).

Den affektiva turen i rad 10 indikerar också att Beas tillkännagivande att hon ska smaka på såsen ( $\operatorname{rad} 7)$ inte primärt gällde arbetsfördelning, i bemärkelsen att en av flera samarbetande parter åtar sig en uppgift. Snarare kan turen förstås som ett verbalt uppvisande av att Bea är i färd med att skaffa relevant epistemisk tillgång. Det är denna kunskap som kommer att ligga till grund för det efterföljande beslutet om hur såsen ska kryddas, och det är denna kunskap som Ida sanktioneras för att hon avstår från att inhämta. 
Efter Beas affektiva invändning etableras det för henne adekvata utförandet av en gemensam avsmakning. Ida plockar åter upp sin sked, rör runt i grytan och tar upp ett smakprov medan Bea kyler ner sitt smakprov på skeden genom att blåsa på den (fig. 5). De smakar sedan under fyra sekunder av såsen utan att titta på varandra (fig. 6). Att sensoriska upplevelser såsom avsmakning görs till något privat och individuellt genom tystnad och avsaknad av ögonkontakt har beskrivits för avsmakning i diverse kontexter (se t.ex. Mondada 2017). Tystnaden och det individuella fokuset fungerar också som uppvisande av epistemisk hållning. Genom noggrann avsmakning och påföljande eftertänksamhet skaffar de sig inte bara samma epistemiska grund att utgå från utan visar även upp för varandra att de nu har tillräcklig kunskap för att göra en kompetent bedömning. När båda deltagarna har inhämtat rätt kunskap kan de gemensamt fatta beslut utifrån de individuella smakupplevelserna. Ida inleder övergången från individuell smakning till att offentliggöra resultaten av sin smakupplevelse med ett förslag Ja tyck $(0,2)$ Lite mer salt $(\operatorname{rad} 15)$.

Detta exempel ger vid handen att det behandlas som otillräckligt deltagande att endast skaffa sig visuell tillgång i en beslutsfattandeprocess som beror av andra sinnen. Samtliga deltagare måste sensoriskt uppleva såsen för att gemensamt kunna fatta beslut om den. Att inte skaffa sig adekvat tillgång till beslutsobjektet och inta en epistemisk hållning kan behandlas som bristande deltagande. Det kan jämföras med exempel (3) ovan, där båda deltagarna vinnlägger sig om att med egna ögon se potatisens färg och yta och därefter fatta beslut om en lämplig åtgärd. Att man kan sanktioneras för att inte skaffa tillgång till det som är föremål för beslutet menar vi är ett argument för att uppvisande av epistemisk tillgång är en avgörande komponent för deltagande i gemensamt beslutsfattande.

\section{Sammanfattning och diskussion}

I den här studien intresserar vi oss för hur deltagare åstadkommer gemensamma beslut och förhåller sig till beslutsprocessen som gemensam. Vi söker grundläggande praktiker i en allmänmänsklig aktivitet, nämligen matlagning, och undersöker vad det är man delar i en gemensam beslutsfattandeprocess. Denna vardagliga aktivitet kräver kompetenta sociala aktörer som kan utföra och förstå sociala handlingar nödvändiga för att driva aktiviteten framåt. Vi kompletterar tidigare forskning som främst har behandlat beslutsfattande i s.k. 


\section{Klara Bertils \& Simon Magnusson}

institutionella miljöer, särskilt med fokus på läkare-patientsamtal. I dessa samtal kan möjligheterna för gemensamt beslutsfattande vara begränsade av kontextens institutionella ramar, såsom en asymmetri mellan deltagarna och en orientering mot olika institutionella roller med olika tillhörande förväntningar på kunskap och handlingsutrymme. I ett läkare-patientsamtal agerar deltagarna utifrån sina institutionella roller som läkare respektive patient, och ett beslut om behandling berör i slutändan främst patienten. I den här studien undersöker vi i stället en vardaglig kontext där deltagarna umgås vänner emellan. Även om det givetvis kan finnas asymmetrier mellan deltagarna även i denna kontext, rör de beslut som fattas av alla deltagare som har ett gemensamt intresse av slutresultatet - en god middag och en trevlig samvaro under matlagningen. Vi menar att studien genom sitt empiriska material av icke-institutionell karaktär fördjupar förståelsen av gemensamt beslutsfattande som socialt fenomen.

För att genomföra gemensamma handlingar tillsammans med andra människor krävs att deltagarna i detalj vet vad den andra gör, samt vilken slags kunskap den besitter och kan förväntas hållas ansvarig för (Goodwin 2013). Omvänt gäller att man för att delta i en aktivitet behöver visa att man deltar på rätt sätt genom att skaffa sig adekvat empiriskt underlag för beslutet. För att undersöka deltagande i beslutsfattandesekvenser har vi i denna undersökning, utifrån en modell för gemensamt beslutsfattande i interaktion (Stevanovic 2012), undersökt hur deltagare gör beslutsfattande till en gemensam angelägenhet. En central del i detta arbete är att skaffa och uppvisa tillgång till det empiriska underlag som beslutet gäller. Att visa varandra att man har tillgång till det som man ska fatta beslut om behandlas i våra exempel som en förutsättning för att delta i beslutsfattandet (jfr Goodwin \& Goodwin 2004). Genom att fokusera den kontextuella konfigurationen (Goodwin 2000) vid beslutsfattandesekvenser i ansikte-mot-ansikte-interaktion som rör den materiella världen kan vi visa hur gemensamhet utöver verbala resurser i hög grad åstadkoms genom deltagarnas kroppar, blickar och hantering av objekt under hela beslutsfattandesekvensen. Vi har visat hur deltagarna genom att inta kroppsliga hållningar kan godta eller avvisa samtalspartnerns förslag, visa att man inhämtar kunskap relevant för beslutet samt upprätthålla en intersubjektiv förståelse för huruvida beslutsfattandet är avslutat eller fortfarande pågår (jfr Stevanovic m.fl. 2017). Vidare menar vi att de sätt som deltagarna orienterar sig mot objekt i rummet är avgörande för att fokusera den gemensamma uppmärksamheten, och för att visa adekvat förståelse och gemensamhet i beslutsgången. Kroppsliga, materiella och sensoriska resurser framstår alltså i vårt material som högst centrala för 
att koordinera beslutsfattandet. Därför vill vi poängtera att ett multimodalt perspektiv är nödvändigt för att analysera och förstå gemensamt beslutsfattande så som det faktiskt utförs och hanteras av människor i interaktion ansikte mot ansikte. Det multimodala perspektivet är inte minst viktigt i en kontext där besluten handlar om att hantera och förändra objekt i den direkt omgivande materiella världen.

Vi argumenterar i linje med tidigare forskning att gemensamt beslutsfattande handlar om att visa upp sitt deltagande genom att inte bara skaffa lämplig kunskap utan också att signalera detta. Med hjälp av bland annat kroppspositionering visar man upp för motparten att man besitter kunskap relevant för den pågående aktiviteten. Genom detta arbete åstadkommer deltagarna uppvisbart välgrundade beslut som utgör byggstenar i den övergripande sociala samvaron.
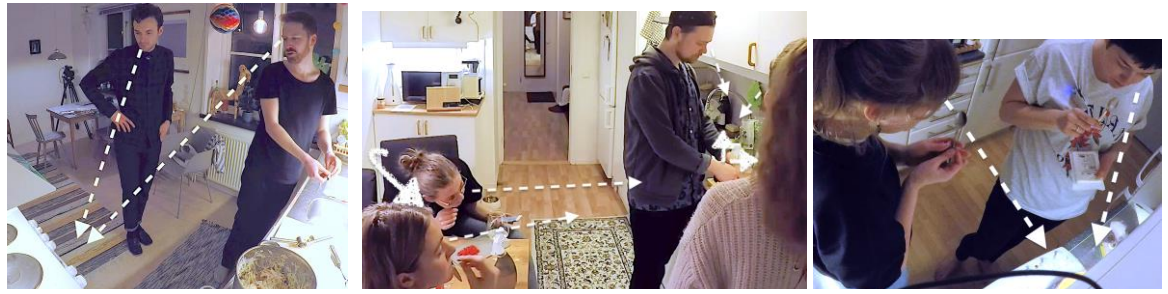

Fig 1-3. Åstadkommande och uppvisande av tillgång.

I vår analys kan vi visa att en deltagare som inte skaffar tillräcklig epistemisk tillgång, som då en deltagare inte smakar på såsen, sanktioneras genom affektiva reaktioner (exempel 4). Detta talar för analysen att uppvisande av tillgång till beslutsobjektet behandlas som en förutsättning för adekvat deltagande i beslutsfattandet. Det pekar också på att just tillgång till beslutsobjektet är någonting som kräver särskilda insatser för deltagande i beslutsfattande. Medan det räcker att en enskild deltagare föreslår en handling eller genomför den fastslagna handlingen, kräver anskaffande av tillgång alla deltagares individuella insats. För att besluta om potatisen är färdig att tas ut ur ugnen eller om såsen är bra kryddad måste bägge parter skaffa sig en enskild perceptuell uppfattning om matens tillstånd. Först därefter kan man diskutera handlingsalternativ och fatta ett underbyggt beslut. Deltagarna utgår från varandras individuella, specifika erfarenheter i bedömningen och gör ett arbete för att jämföra sina perceptioner och sträva mot en intersubjektiv uppfattning. Det räcker inte att en av deltagarna smakar och att vederbörandes bedömning kan gälla för samtliga, utan deltagarna orienterar sig mot varandras uppfattningar som unika och varje deltagares eget bidrag som nödvändigt. En viktig del i det gemensamma är så- 


\section{Klara Bertils \& Simon Magnusson}

ledes att dela och jämföra sina individuella uppfattningar, och gemensamhet och deltagande görs genom att införskaffa och beakta varje persons unika, specifika bidrag till den gemensamma processen. Det faktum att adekvat deltagande tycks innebära att införskaffa och uppvisa individuell kunskap gör besluten till verkligt delade, då varje deltagares unika uppfattning och insats möjliggör ett välgrundat gemensamt beslut. En central del i att göra någonting till gemensamt är att beakta och värdesätta det unika och subjektiva.

Stevanovic (2012) menar att deltagare genom att konstruera beslut som gemensamt fattade skapar samhörighet. Samhörighet tycks uppnås genom att man behandlar varandra som medansvariga deltagare i aktiviteten, och därigenom gör den till gemensam. I denna studie har vänner samlats för att umgås, laga mat och dricka vin tillsammans. Det delade beslutsfattandet förefaller här vara en viktig beståndsdel i aktiviteten, inte bara för att undvika att bli ensam ansvarig för hur maten smakar utan som en praktik för att göra gemenskap.

\section{Litteratur}

Barnes, Rebecca, 2017: Preliminaries to Treatment Recommendations in UK Primary Care: A Vehicle for Shared Decision Making? I: Health Communication 33(11). S. 1366-1376.

Bergmann, Jörg, 1990: On the local sensitivity of conversation. I: I. Markovà \& K. Foppa (red.): The Dynamics of Dialogue. Hertsfordshire: Harvester Wheatsheaf. S. 201-226.

Charles, Cathy, Gafni, Amiram \& Whelan, Tim, 1997: Shared decision-making in the medical encounter: what does it mean? (or it takes at least two to tango). I: Social Science \& Medicine 44(5). S. 681-692.

Collins, Sarah, Drew, Paul, Watt, Ian \& Entwistle, Vikki, 2005: 'Unilateral' and 'bilateral' practitioner approaches in decision-making about treatment. I: Social Science \& Medicine 61(12). S. 2611-2627.

Conein, Bernard, 1997: L'action avec les objets: Un autre visage de l'action située? I: Raisons pratiques 8. S. 25-45.

Costello, Brian \& Roberts, Felicia, 2001: Medical Recommendations as Joint Social Practice. I: Health Communication 13(3). S. 241-260.

Couper-Kuhlen, Elizabeth, 2012: Exploring Affiliation in the Reception of Conversational Complaint Stories. I: Emotion in Interaction. Oxford: Oxford University Press. S. 113-144.

Day, Dennis \& Wagner, Johannes, 2014: Objects as tools for talk. I: M. Nevile, P. Haddington, T. Heinemann \& M. Rauniomaa (red.): Interacting with Objects. Amsterdam: John Benjamins Publishing Company. S. 101-124. 
Goffman, Ervin, 1981: Footing. I: Forms of Talk. Oxford: Blackwell. S. 124-159.

Goldberg, Jo Ann, 1975: A system for the transfer of instructions in natural settings. I: Semiotica 14(3). S. 269-296.

Goodwin, Charles, 2000: Action and embodiment within situated human interaction. I: Journal of Pragmatics 32(10). S. 1489-1522.

Goodwin, Charles, 2007: Participation, stance and affect in the organization of activities. I: Discourse \& Society, 18(1). S. 53-73.

Goodwin, Charles, 2013: The co-operative, transformative organization of human action and knowledge. I: Journal of Pragmatics 46(1). S. 8-23.

Goodwin, Charles \& Duranti, Alessandro, 1992: Rethinking context: An introduction. I: C. Goodwin \& A. Duranti (red.): Rethinking context: Language as an interactive phenomenon. Cambridge: University Press. S. 1-42.

Goodwin, Charles \& Goodwin, Marjorie, 2004: Participation. I: A. Duranti (red.): A Companion to Linguistic Anthropology. Malden, MA: Blackwell Publications. S. 222-244.

Heritage, John. 1984: Garfinkel and ethnomethodology. Cambridge: Polity Press.

Heritage, John, 2012: Epistemics in Action: Action Formation and Territories of Knowledge. I: Research on Language and Social Interaction 45(1). S. 1-29.

Houtkoop, Hanneke, 1987: Establishing agreement: An analysis of proposal-acceptance sequences. Dordrecht: Foris Publications.

Hultberg, Josabeth \& Rudebeck, Carl Edvard, 2017: Patient participation in decisionmaking about cardiovascular preventive drugs: resistance as agency. I: Scandinavian Journal of Primary Health Care 35(3). S. 231-239.

Jefferson, Gail, 2004: Glossary of transcript symbols with an introduction. I: Conversation Analysis: Studies from the first generation. Amsterdam: John Benjamins. S. 1331.

Kaukomaa, Timo, Peräkylä, Anssi \& Ruusuvuori, Johanna, 2014: Foreshadowing a problem: Turn-opening frowns in conversation. I: Journal of Pragmatics 71. S. 132147.

Keisanen, Tiina \& Rauniomaa, Mirka, 2012: The Organization of Participation and Contingency in Prebeginnings of Request Sequences. I: Research on Language and Social Interaction 45(4). S. 323-351.

Koenig, Christopher, 2011: Patient resistance as agency in treatment decisions. I: Social Science \& Medicine 72(7). S. 1105-1114.

Landmark, Anne Marie Dalby, 2016: Negotiating patient involvement in treatment decision making: A conversation analytic study of Norwegian hospital encounters (Diss). Institutt for klinisk medisin, Universitetet i Oslo.

Landmark, Anne Marie Dalby, Gulbrandsen, Pål \& Svennevig, Jan, 2015: Whose decision? Negotiating epistemic and deontic rights in medical treatment decisions. I: Journal of Pragmatics 78. S. 54-69.

Lindström, Anna \& Weatherall, Ann, 2015: Orientations to epistemics and deontics in treatment discussions. I: Journal of Pragmatics 78. S. 39-53.

Mondada, Lorenza, 2014a: Cooking instructions and the shaping of things in the kitchen. I: M. Nevile, P. Haddington, T. Heinemann \& M. Rauniomaa (red.): Interacting with Objects. Amsterdam: John Benjamins Publishing Company. S. 199226. 


\section{Klara Bertils \& Simon Magnusson}

Mondada, Lorenza, 2014b: Conventions for multimodal transcription. https://franz.unibas.ch/fileadmin/franz/user_upload/redaktion/Mondada_conv_multimodality.pdf

Mondada, Lorenza, 2017: Tasting together: Multisensorial intersubjective experiences in interaction. Plenarföreläsning, 11 maj 2017 vid konferensen Intersubjectivity in interaction, Helsingfors universitet.

Mondada, Lorenza, 2018a: Multiple Temporalities of Language and Body in Interaction: Challenges for Transcribing Multimodality. I: Research on Language and Social Interaction 51(1). S. 85-106.

Mondada, Lorenza, 2018b: Visual practices: video studies, multimodality and multisensoriality. I: D. Favareau (red.): Co-operative Engagements in Intertwined Semiosis: Essays in Honour of Charles Goodwin. Tartu: University of Tartu Press. S. 304-325.

Mondada, Lorenza, 2018c: The multimodal interactional organization of tasting: Practices of tasting cheese in gourmet shops. I: Discourse Studies 20(6). S. 743-769.

Mondada, Lorenza, 2019: Rethinking bodies and objects in social interaction: A multimodal and multisensorial approach to tasting. I: U. Tikvah Kissmann \& J.van Loon (red.): Discussing New Materialism: Methodological Implications for the Study of Materialities. Berlin: Springer. S. 109-134.

Mondada, Lorenza, u.å: Taste and Connoisseurship in Social Interaction. Cambridge: Cambridge University Press.

Nevile, Maurice, Haddington, Pentti, Heinemann, Trine \& Rauniomaa, Mirka, 2014: On the interactional ecology of objects. I: M. Nevile, P. Haddington, T. Heinemann \& M. Rauniomaa (red.): Interacting with Objects. Amsterdam: John Benjamins Publishing Company. S. 3-26.

Raevaara, Liisa, 2017: Adjusting the design of directives to the activity environment. I: M.-L. Sorjonen, L. Raevaara \& E. Couper-Kuhlen (red.): Imperative Turns at Talk: The design of directives in action. Amsterdam: John Benjamins Publishing Company. S. 381-410.

Rauniomaa, Mirka \& Heinemann, Trine, 2014: Organising the soundscape. I: M. Nevile, P. Haddington, T. Heinemann \& M. Rauniomaa (red.): Interacting with Objects. Amsterdam: John Benjamins Publishing Company. S. 145-168.

Robinson, Jeffrey, 2003: An Interactional Structure of Medical Activities During Acute Visits and Its Implications for Patients' Participation. I: Health Communication 15(1). S. 27-59.

Schegloff, Emanuel, 1996: Confirming Allusions: Toward an Empirical Account of Action. I: American Journal of Sociology 102(1). S. 161-216.

Schegloff, Emanuel, 1998: Body Torque. I: Social Research 65(3). S. 535-596.

Schegloff, Emanuel, 2007: Sequence Organization in Interaction: A Primer in Conversation Analysis. Vol. 1. Cambridge: Cambridge University Press.

Socialstyrelsen, 2012: Shared decision making - en introduktion till delat beslutsfattande inom psykiatrisk vård. Stockholm: Socialstyrelsen.

Stasser, Garold \& Stewart, Dennis, 1992: Discovery of hidden profiles by decisionmaking groups: Solving a problem versus making a judgment. I: Journal of Personality and Social Psychology 63(3). S. 426-434.

Stevanovic, Melisa, 2012: Establishing joint decisions in a dyad. I: Discourse Studies 14(6). S. 779-803. 
Stevanovic, Melisa, Himberg, Tommi, Niinisalo, Maija, Kahri, Mikko, Peräkylä, Anssi, Sams, Mikko \& Hari, Riitta, 2017: Sequentiality, Mutual Visibility, and Behavioral Matching: Body Sway and Pitch Register During Joint Decision Making. I: Research on Language and Social Interaction 50(1). S. 33-53.

Stevanovic, Melisa \& Monzoni, Chiara, 2016: On the hierarchy of interactional resources: Embodied and verbal behavior in the management of joint activities with material objects. I: Journal of Pragmatics 103. S. 15-32.

Stevanovic, Melisa \& Peräkylä, Anssi, 2012: Deontic Authority in Interaction: The Right to Announce, Propose, and Decide. I: Research on Language and Social Interaction 45(3). S. 297-321.

Stivers, Tanya, 2005a: Non-antibiotic treatment recommendations: delivery formats and implications for parent resistance. I: Social Science \& Medicine 60(5). S. 949 964.

Stivers, Tanya, 2005b: Parent Resistance to Physicians' Treatment Recommendations: One Resource for Initiating a Negotiation of the Treatment Decision. I: Health Communication 18(1). S. 41-74.

Stivers, Tanya, 2006: Treatment decisions: Negotiations between doctors and parents in acute care encounters. I: J. Heritage \& D. Maynard (red.): Communication in Medical Care: Interaction Between Primary Care Physicians and Patients. (Studies in Interactional Sociolinguistics). Cambridge: Cambridge University. S. 279-312.

Stivers, Tanya, Heritage, John, Barnes, Rebecca K., McCabe, Rose, Thompson, Laura \& Toerien, Merran, 2017: Treatment Recommendations as Actions. I: Health Communication. 33(11). S. 1335-1344.

Stukenbrock, Anja, 2012: Empraxis und Displacement: Überblendete Räume in der Koch-Show-Interaktion. I: H. Hausendorf, L. Mondada \& R. Schmitt (red.): Raum als interaktive Ressource. Tübingen: Narr Verlag. S. 347-380.

Toerien, Merran, Shaw, Rebecca \& Reuber, Markus, 2013: Initiating decision-making in neurology consultations: 'recommending' versus 'option-listing' and the implications for medical authority. I: Sociology of Health \& Illness 35(6). S. 873-890.

Tomasello, Michael, 1999: The cultural origins of human cognition. Cambridge, Massachusetts: Harvard University Press.

Ursi, Biagio, 2016: «Et c'est qui le chef ? »: Négociations et manifestations du désaccord pendant la préparation de repas. Les cahiers de praxématique 67. http:// journals.openedition.org/praxematique/4448.

Vetenskapsrådet, 2002: Forskningsetiska principer inom humanistisk-samhällsvetenskaplig forskning. Stockholm: Vetenskapsrådet.

Wiggins, Sally \& Potter, Jonathan, 2003: Attitudes and evaluative practices: Category vs. item and subjective vs. objective constructions in everyday food assessments. I: British Journal of Social Psychology 42(4). S. 513-531.

Wiggins, Sally, Potter, Jonathan \& Wildsmith, Aimee, 2001: Eating Your Words: Discursive Psychology and the Reconstruction of Eating Practices. I: Journal of Health Psychology 6(1). S. 5-15. 


\section{Transkriptionsnyckel för verbal transkription (Jefferson 2004)}

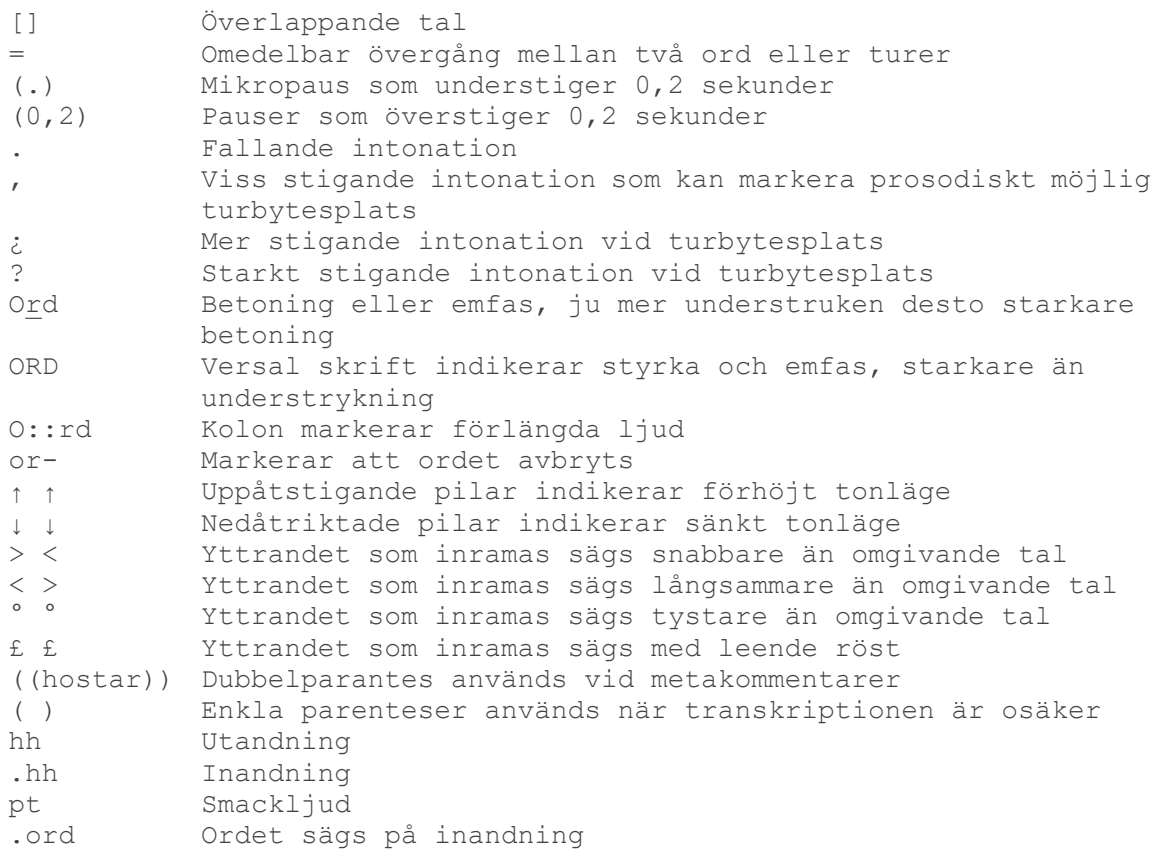

\section{Transkriptionsnyckel för multimodal transkription (Mondada 2014b)}

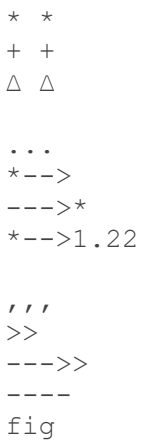

Multimodala handlingar avgränsas mellan två identiska symboler. Dessa avgränsningar placeras ut på den verbala raden som utgör tidslinje även för de kroppsliga handlingarna.

Handlingen förbereds

Handlingen fortsätter tills symboler dyker upp igen och markeras som avslutad i transkriptionen

En handling som pågår länge kan också markeras med startoch slutrad

Handlingen återgår

Handlingen börjar innan transkriptionsexemplet

Handlingen fortsätter efter transkriptionsexemplets slut Handlingen har nått sin apex

Exakt ögonblick markerad med \# i den verbala raden för när en skärmdump av videon tagits 